\title{
The lion with wings: innovation system dynamics in the aerospace industry of Singapore
}

\author{
Daniel Vertesy \\ UNU-MERIT, \\ Keizer Karelplein 19, \\ 6211TC Maastricht, The Netherlands \\ and \\ Joint Research Centre of the European Commission, \\ Via E. Fermi 2749, 21027 Ispra (VA), Italy \\ and \\ Corvinus University of Budapest, \\ Fővám tér 8, 1093 Budapest, Hungary \\ E-mail: vertesy@merit.unu.edu
}

\begin{abstract}
This paper investigates the emergence and growth of Singapore's aerospace manufacturing industry. Singapore is unique among latecomers in the sector, because of the continuous growth it achieved by establishing world-class component manufacturing and maintenance, repair and overhaul facilities. We use a sectoral innovation system dynamics framework to analyse the evolution of institutions and technological capabilities in the sector. Empirical evidence on innovative and productive activities shows that a strategic choice of openness, in addition to the strong linkages between companies and between industry and government facilitated the emergence of a sectoral innovation system early on. We also find that the initial choice of specialisation and the close embeddedness of the sectoral innovation system in the national innovation system allowed Singapore to flexibly respond to global and regional crises in the sector and sustain growth.
\end{abstract}

Keywords: aircraft industry; Singapore catching up; sectoral systems of innovation; maintenance, repair and overhaul; MRO.

Reference to this paper should be made as follows: Vertesy, D. (2013)

'The lion with wings: innovation system dynamics in the aerospace industry of Singapore', Int. J. Technology and Globalisation, Vol. 7, Nos. 1/2, pp.118-140.

Biographical notes: Daniel Vertesy obtained his $\mathrm{PhD}$ at United Nations University/Maastricht University (UNU-MERIT) in 2011. His $\mathrm{PhD}$ project focused on innovation system dynamics in latecomer aerospace industries in emerging economies. Currently, he is a Post-doc Researcher at the Joint Research Centre of the European Commission.

\section{Introduction}

With a total area of 697 square kilometres, with natural resources limited to the strategic waterways of the Strait, the deep-water ports and fish, Singapore may seem like an odd location for specialising in aerospace manufacturing. But history has proven that the size 
of the domestic market is not necessarily a limit to success and that a well-functioning innovation system can also be built around repair and production in the lower tiers of the industry. Today, Singapore is the second-largest latecomer aerospace producer in the emerging world in terms of value added and is outperforming even Brazil. Between 1977 and 2007 production in Singapore grew almost constantly, with the exception of only three years. This is highly remarkable for an open economy in such a volatile sector.

This study explores two questions. How did the aerospace industry and innovation system emerge in Singapore? What characterised the co-evolution of technological capabilities and firm growth over time and how did the industry sustain growth over the last 40 years, uniquely among newly emerging economies in aerospace?

This paper employs a sectoral innovation system dynamics framework which is briefly outlined in this section below. Section 2 provides a historical-institutional overview of the emergence of the industry and innovation system. It analyses the role of the government (including the air force) in overcoming latecomer disadvantages, providing the financial and institutional framework and opening channels of technological flow. Section 3 focuses on the fundamental changes that took place at the early 1990s that increased the self-sustaining capabilities of the innovation and production system. Finally, Section 4 summarises the unique co-evolution of firms, institutions and technologies in Singapore, and discusses the reasons for the successful catch-up of the Singaporean aerospace industry and contrasts it with other latecomer cases.

\subsection{The evolution of innovation systems}

Latecomer industries face multiple barriers: a lack of technological capabilities and a lack of market access (Hobday, 1995). Latecomer industrialisation, especially in complex, high-tech industries, depended on a significant degree of government intervention (Cimoli et al., 2009; Kim, 1980, 1997; Lall, 1992, 2004). The substantial initial infrastructural, physical and human capital barriers for the initial development of the aerospace industry required a joint targeting by industrial, science, technology and innovation, higher education, and trade policies.

The sectoral systems of innovation framework (Malerba, 2004) provides a rich set of tools to explore the co-evolution of firms, organisations, technological capabilities, institutions in aerospace (Marques, 2004; Niosi and Zhegu, 2008; Mani, 2010). Among the main functions of an innovation system, the adoption, diffusion and creation of new knowledge and technologies, the first two are the most crucial in a latecomer context. Especially during the early period when main elements of the system are non-existent or underdeveloped, an innovation system is virtually a learning system, which facilitates the actors (firms, but also non-firm organisations, such as research institutes or policy maker bodies) to acquire existing technologies, or good practices. The eventual introduction of efficiency-improving process innovations and new products depend on the continued success of the learning process. The functioning of the system depends on rules (institutions in the sense of North) that condition the interactions between system actors. These include the removal of barriers to financing learning and innovative activities or barriers to the flow of technological knowledge or expertise embedded in people.

Due to the discontinuities in technological development at the world frontier (Freeman and Perez, 1988; Freeman and Soete, 1997; Perez and Soete, 1988) and the presence of punctuated equilibriums in the long-run evolution of firms, organisations and 
industries (Abernathy and Utterback, 1978; Romanelli and Tushman, 1994; Tushman and Anderson, 1986), the long-run evolution of innovation systems include similar interruptions. We have shown elsewhere that the long-run evolution of latecomer aerospace industries require a framework that can grasp both radical and incremental changes in sectoral systems of innovation in aerospace. The interruptions occur as a result of declining competitiveness and macro-economic shocks and involve a decline in innovative performance and industrial output. A transition to a new growth trajectory may follow if fundamental institutional changes take place to meet the changed competitive environment. In most cases, interruptions and transitions are associated with a stagnation or decline in industrial output (Vertesy and Szirmai, 2010). In this paper, we further explore the interrupted innovation framework by tracking the institutional development of the aircraft industry in Singapore and innovation system from the years of emergence in search of radical system changes.

\section{The development trajectory of the Singapore aerospace innovation system}

\subsection{Background: industrialisation and innovation in Singapore}

By the end of the 1970s when the government of Singapore decided to promote the development of the aerospace industry, the manufacturing sector had already strengthened in the country. The two fundamental conditions for earlier industrial growth were, according to Aw (1991), political stability and an investor-friendly business climate. The People's Action Party (PAP) has been continuously ruling Singapore with a high approval rating ${ }^{1}$ since before the island state's independence from the Federation of Malaysia in 1965. A system of centralised decision making was established that prioritised economic competitiveness and efficiently fought corruption. National security was a high priority after the independence of Singapore given the not-so-friendly relations with its neighbours in the initial years. The Economic Development Board (EDB) was established in 1961 for strategic planning and investment promotion. An Export Promotion Centre was created in 1965 to provide export financing and credit insurance to exporters. Trade unions were kept under control by an umbrella organisation which was incorporated into the PAP structure since 1964. The 1968 Employment Act strengthened the power of employers and reduced the scope of collective bargaining for employees, but a tripartite forum, the National Wages Council was a main tool to incorporate workers in long-term growth negotiations since 1972. Aw (1991) emphasised that public housing for middle and lower classes was significantly reduced social tensions, and workers subscribed to investor-friendly reforms given a culture that valued thrift, readiness to change and social mobility, a free enterprise market, and consistent, predictable and rational policy making. The pro-industrialisation policies had tangible results. The average annual growth rate was $13.2 \%$ between 1968 and 73 , and $8.5 \%$ between 1974 and 1982. This took place along structural transformation, in which the share of industry in GDP increased from $19 \%$ in 1960 to $30 \%$ in 1980, and the share of manufacturing in GDP increased over the same period from $13 \%$ to $22.3 \%$. In the $1960 \mathrm{~s}$, around half of the domestic investment was financed by national savings, which increased to over two-third from the 1970s. Foreign investment was most pervasive in the manufacturing sector, increasing from $45 \%$ in 1966 to $81 \%$ in 1979 . This was also 
spurred by the externalisation of the US economy and an explicit US strategy to develop Southeast Asia to contain Soviet influence in the region.

Table 1 The performance of Singapore's national innovation system, 1990-2009

\begin{tabular}{|c|c|c|c|c|c|}
\hline & 1990 & 1995 & 2000 & 2005 & 2009 \\
\hline $\begin{array}{l}\text { Gross expenditure on R\&D } \\
(\text { USD mln) }\end{array}$ & 382 & 780 & 1,746 & 2,658 & 3,271 \\
\hline GERD/GDP (\%) & 0.81 & 1.11 & 1.85 & 2.19 & 2.28 \\
\hline $\begin{array}{l}\text { Business expenditure on } \\
\text { R\&D/GDP (\%) }\end{array}$ & 0.44 & 0.71 & 1.15 & 1.45 & 1.41 \\
\hline $\begin{array}{l}\text { Researchers in science and } \\
\text { engineering }\end{array}$ & 4,329 & 8,340 & 14,483 & 21,338 & 26,608 \\
\hline $\begin{array}{l}\text { Annual PCT patent } \\
\text { applications }\end{array}$ & 1 & 26 & 203 & 444 & 598 \\
\hline $\begin{array}{l}\text { Scientific and technical } \\
\text { journal articles (cumul.) }\end{array}$ & 572 & 1,141 & 2,361 & 3,611 & $3,792^{\mathrm{c}}$ \\
\hline $\begin{array}{l}\text { In the field of aerospace } \\
\text { and aeronautics }{ }^{\mathrm{b}}\end{array}$ & 21 & 95 & 685 & 1,317 & 1,738 \\
\hline \multirow{3}{*}{$\begin{array}{l}\text { Hi-tech exports' share in } \mathrm{mfg} \text {. } \\
\text { exports }(\%)\end{array}$} & 39.7 & 53.9 & 62.6 & 56.6 & $50.8^{\mathrm{d}}$ \\
\hline & \multicolumn{5}{|c|}{ Average annual growth rates (\%) } \\
\hline & 1990-1995 & $1995-2000$ & & $2000-2005$ & $2005-2009$ \\
\hline Gross expenditure on $\mathrm{R} \& \mathrm{D}$ & 15.3 & 17.5 & & 8.8 & 5.3 \\
\hline GERD/GDP & 6.5 & 10.8 & & 3.4 & 1.0 \\
\hline $\begin{array}{l}\text { Business expenditure on } \\
\text { R\&D/GDP }\end{array}$ & 10.0 & 10.1 & & 4.7 & -0.7 \\
\hline $\begin{array}{l}\text { Researchers in science and } \\
\text { engineering }\end{array}$ & 14.0 & 11.7 & & 8.1 & 5.7 \\
\hline PCT patent applications & 91.1 & 51.5 & & 16.9 & 7.7 \\
\hline $\begin{array}{l}\text { Scientific and technical } \\
\text { journal articles }\end{array}$ & 14.8 & 15.7 & & 8.9 & 2.5 \\
\hline $\begin{array}{l}\text { In the field of aerospace } \\
\text { and aeronautics }\end{array}$ & 35.2 & 48.5 & & 14.0 & 14.9 \\
\hline $\begin{array}{l}\text { Hi-tech exports' share in mfg. } \\
\text { exports }\end{array}$ & 6.3 & 3.0 & & -2.0 & -3.5 \\
\hline
\end{tabular}

Notes: ${ }^{\mathrm{a} U S D}$ million in constant 2000 prices.

${ }^{\mathrm{b}}$ Includes 42 journals, for definition see Science Metrix Ontology 103.

${ }^{\mathrm{c}}$ Data refers to 2007.

${ }^{\mathrm{d}}$ Refers to 2008 .

Source: National Survey of R\&D in Singapore 2009, Agency for Science,

Technology and Research; World Development Indicators Online

Singapore followed a strategy of export promotion and has targeted 'non-traditional' industries already since 1959. There was a shift in the promoted industries toward technology-intensive sectors (shipbuilding, electrical and non-electrical machinery, appliances and supplies, and transport equipment) in the mid-1970s. With the provision 
of loan subsidies, two-third of all loan commitments went into the promoted sectors by 1975.

Education reforms aimed at improving human resources in science and technology. For instance, foreseeing local industries' future demand, the University of Singapore launched several master programmes in engineering in the early 1970s and expanded its facilities. Additionally, on-the-job training was a major way of acquiring skills at foreign-owned companies. Since the early 1970s, Singapore achieved near-full employment and migration policy was highly regulated to follow business cycles and skills demand.

Put simply, Singapore's economy underwent two major transformations over the last four decades. In the late 1970s, it shifted from labour-intensive to capital-intensive, high-value-added manufacturing. Responding to increasing competition in the region and the lack of natural resources, Singapore recognised the need to shift to knowledge-intensive activities and services which occurred at the beginning of the 1990s. Explicit innovation policies and strategies were devised by the EDB and a National Science and Technology Board (NSTB) was established in 1991 to implement them in two-year technology plans. The government was also pushing for reforms in higher and vocation education. Already since 1978, Singapore has been systematically monitoring R\&D activities. In the 1990s, strong incentives were offered to boost total R\&D expenditures to above $2 \%$ of the GDP by the year 2000. A national innovation system relied on intensive interactions between the private sector, the EDB (which was responsible for innovation and FDI strategies), and the NSTB (which was renamed to Agency for Science, Technology and Research or 'A-Star' in 2002). In this structure, strategic planning meetings were held regularly since 1987 and competitive challenges could be reacted upon rather quickly. Information exchange was also intensive between employers, employees and the state agencies in a corporatist, tripartite structure (Yun, 2004).

Table 1 gives a general overview of the results of the innovation policies. Between 1990 and 2009 R\&D expenditures increased six-fold. Compared with GDP, total R\&D expenditures increased from 0.81 in 1990 to 2.28. After the rapid growth in key dimensions of the innovation system in the 1990s, there is a slow-down in the new millennium, but the growth is still impressive in light of the several crises that hit the outward-oriented economy over the last 15 years, from the Asian financial crisis through 9/11 and the SARS crises to the most recent global financial crisis.

\subsection{The emerging aircraft manufacturing industry (1970s-1980s)}

The emergence of the industry can be attributed to the increased demand for local technological capabilities to maintain, repair and overhaul the fleets of both the Republic of Singapore Air Force (RSAF) ${ }^{2}$ and of Singapore Airlines (SIA) during the 1970s. Aerospace manufacturing was given a priority industry status due to its high value-added, skills intensive nature along with other industries such as electronics, computers or medical equipment. Alongside, Singapore was also seen as a potential regional aviation headquarters for Southeast Asia. The combination of national security and commercial aims offered substantial synergies to make use of military and commercial technology and to raise private investment in the emerging industry. The RSAF was an important customer for maintenance and upgrade services of its fighter and trainer fleet, and the growing East Asian commercial aviation market was supposed to cater demand for a new 
regional maintenance, repair and overhaul (MRO) hub that could benefit from the strategic location.

Attracting foreign investors turned out to be too big of a challenge during the 1970s. According to Hill and Pang (1988), this could be explained by four factors:

1 lack of a regional market for components

2 difficulty in sourcing raw materials

3 lack of a bilateral agreement with a foreign certifying authority (e.g., the Federal Aviation Authority of the USA) ${ }^{3}$

4 uncertainty about the availability of skilled labour force.

The government's response was the introduction of a reform package in 1979. Incentives were offered to invest in the priority industries, including corporate tax exemption for the first five years after production start-up. ${ }^{4}$ In order to attract skilled labour force, a corrective wage policy was implemented and education and training institutions were expanded, especially in science and engineering fields. A bilateral Airworthiness Agreement was signed with the USA in 1981 to mutually accept national certification. Further important steps were the organisation of the Asian Aerospace Exhibitions starting in 1981 and the opening of a new airport at Changi. The airport has quickly become a major hub in South East Asia, giving home to the globally expanding SIA, but also to other airlines making a stopover here en route to Australia, Europe, the Middle East or Asia.

In 1981, former aviation contractor firms owned by the Ministry of Defence were reorganised into a new state-owned company, Singapore Aircraft Industries (SAI). SAI consisted of five subsidiaries and two associate companies. ${ }^{5}$ The most important of these was SAMCO, which was established in 1975, with a profile in avionics and systems overhaul. As shown in Table 2, SAI has quickly accumulated capabilities to upgrade fighters and trainers and manufacture trainers and helicopters under license. It was assigned to refurbish Douglas A-4 fighters and trainers. By 1985, it has modernised some 80 of this type for the RSAF. In 1985, it was the first company outside Italy to receive a license to assemble the Marchetti S-211 jet trainers. In 1986, SAI also successfully accomplished the re-engining of an A-4 with a General Electric (GE) turbofan. The company was subsequently contracted by the RSAF to re-engine and upgrade avionics on another 50 of these fighters and trainers. During the early 1990 s, further refurbishment programmes involved expanding the lifespan and converting 28 F-5 fighters to reconnaissance configuration and upgrading the rest of the fleet with state-of-the-art radar, avionics and weapons delivery systems. ${ }^{6}$ The refurbishment projects provided opportunities for technological collaboration with a number of established aerospace companies, including Douglas, Northrop and GE from the USA and Aermacchi and Galileo Avionica from Italy.

Already at the end of the 1970s, SAMCO and the Helicopter Division of French Aerospatiale established a joint venture (Samaero) at the Seletar Airport to provide helicopter maintenance services in the region. The oil exploration activities in the region and military procurement by RSAF offered a growing market for utility helicopters. An important milestone was the local assembly of 17 Aerospatiale's medium sized AS-532 
Cougar and AS-332 Super Puma models from kits between 1985 and 1988. During 1991 to 1992, the smaller AS-350 Squirrel and 550 Fennec helicopters ${ }^{7}$ were assembled from kits in Singapore (Table 2). At the same time, the effects of the investment incentives as well as the rapidly increasing volume of passenger and cargo air traffic made a mark on the commercial segment of the industry. Between 1973 and 1990, air freight increased at an average rate of $20 \%$, the number of passengers carried increased at an average rate of $11 \%$ (see Table 3). In the aerospace industry, the number of aerospace firms doubled to 18 between 1980 and 1985 .

Table 2 Major local assembly and upgrading projects at Singapore Technologies Aerospace and its predecessors (1974-2007)

\begin{tabular}{|c|c|c|c|c|}
\hline Aircraft model & $\begin{array}{c}\text { Collaborating } \\
\text { company } \\
\text { (HQ country) }\end{array}$ & $\begin{array}{l}\text { Total } \\
n r . \\
\text { built }\end{array}$ & $\begin{array}{l}\text { Years of } \\
\text { production }\end{array}$ & Notes \\
\hline \multicolumn{5}{|l|}{ Fighters/trainers } \\
\hline A-4B Skyhawk & Douglas (USA) & 32 & 1974-1977 & $\begin{array}{l}\text { Modernised with US } \\
\text { components }\end{array}$ \\
\hline A-4C Skyhawk & Douglas (USA) & $40^{\mathrm{u}}$ & 1980-1981 & $\begin{array}{l}\text { Modernised with US } \\
\text { components; license } \\
\text { received from Douglas }\end{array}$ \\
\hline A-4B Skyhawk & Douglas (USA) & $8^{\mathrm{u}}$ & 1983-1984 & $\begin{array}{l}\text { Upgraded with US } \\
\text { components to trainers }\end{array}$ \\
\hline S-211 trainer & $\begin{array}{c}\text { Marchetti/ } \\
\text { Aermacchi/(I) }\end{array}$ & 24 & 1984-1987 & $\begin{array}{l}\text { Assembled under } \\
\text { license }\end{array}$ \\
\hline A-4B Skyhawk & $\begin{array}{l}\text { Douglas; General } \\
\text { Electric (USA) }\end{array}$ & 24 & 1989-1990 & $\begin{array}{l}\text { Re-engined; } \\
\text { modernised with } \\
\text { US components }\end{array}$ \\
\hline \multirow[t]{2}{*}{ F-5 Tiger } & $\begin{array}{l}\text { Galileo Avionica/ } \\
\text { Finmeccanica/ } \\
\text { (I); Elbit (ISR) }\end{array}$ & 28 & 1990 & $\begin{array}{l}\text { Converted to } \\
\text { reconnaissance } \\
\text { configuration }\end{array}$ \\
\hline & & $40^{\mathrm{u}}$ & $1994-$ & $\begin{array}{l}\text { Upgraded with new } \\
\text { radar, avionics and } \\
\text { weapons systems; } \\
\text { subsequently (1998) } \\
\text { offered upgrade } \\
\text { service to Turkey } \\
\text { and Brazil }\end{array}$ \\
\hline F-16C/D & $\begin{array}{l}\text { BAe Systems } \\
\text { (UK) }\end{array}$ & & $1996-$ & $\begin{array}{l}\text { Cockpit avionics } \\
\text { upgrade to 'Falcon } \\
\text { One' }\end{array}$ \\
\hline \multicolumn{5}{|l|}{ Transports } \\
\hline C-130 Hercules & $\begin{array}{l}\text { Rockwell Collins } \\
\text { (USA) }\end{array}$ & 10 & $\begin{array}{l}2007- \\
(2014)\end{array}$ & $\begin{array}{l}\text { Avionics; systems } \\
\text { upgrade (also exports } \\
\text { upgrade service for } \\
\text { Indonesia) }\end{array}$ \\
\hline
\end{tabular}

Notes: (u) number is unconfirmed.

Source: SIPRI; Flight International, various articles 
Table 2 Major local assembly and upgrading projects at Singapore Technologies Aerospace and its predecessors (1974-2007) (continued)

\begin{tabular}{lcccl}
\hline Aircraft model & $\begin{array}{c}\text { Collaborating } \\
\text { company } \\
\text { (HQ country) }\end{array}$ & $\begin{array}{c}\text { Total } \\
\text { nr. } \\
\text { built }\end{array}$ & $\begin{array}{c}\text { Years of } \\
\text { production }\end{array}$ & \multicolumn{1}{c}{ Notes } \\
\hline $\begin{array}{l}\text { Helicopters } \\
\text { AB-205 }\end{array}$ & Bell (USA) & 6 & 1984 & $\begin{array}{l}\text { Modernised; second- } \\
\text { hand from Bangladesh } \\
\text { and Kuwait }\end{array}$ \\
$\begin{array}{l}\text { AS-332, Super Puma } \\
\text { AS-532 Cougar }\end{array}$ & $\begin{array}{c}\text { Aerospatiale/ } \\
\text { Eurocopter/(F) }\end{array}$ & 17 & $1985-1988$ & $\begin{array}{l}\text { Assembled from kits } \\
\text { under license }\end{array}$ \\
AS-350 Squirrel & $\begin{array}{c}\text { Aerospatiale/ } \\
\text { Eurocopter/(F) }\end{array}$ & 20 & $1991-1992$ & $\begin{array}{l}\text { Assembled from kits } \\
\text { under license }\end{array}$ \\
EC-120 & $\begin{array}{c}\text { Eurocopter (EU) } \\
\text { and CATIC (PRC) }\end{array}$ & & $1990-$ & $\begin{array}{l}\text { Co-development; } \\
15 \% \text { stake }\end{array}$ \\
AS-332 Super Puma & & $2002-$ & \begin{tabular}{l} 
Upgrade \\
\hline
\end{tabular}
\end{tabular}

Notes: (u) number is unconfirmed.

Source: SIPRI; Flight International, various articles

Table 3 Growth of passenger and cargo air traffic in Singapore, 1973-2009

\begin{tabular}{lccccccc}
\hline & 1973 & 1985 & 1990 & 1995 & 2000 & 2005 & 2009 \\
\hline Registered carrier departures & 21,300 & 31,100 & 30,500 & 51,600 & 71,042 & 77,119 & 83,772 \\
Passengers carried (million) & 1,249 & 4,912 & 7,046 & 10,779 & 16,704 & 17,744 & 18,427 \\
Air freight, (million ton-km) & 68 & 981 & 1,652 & 3,687 & 6,005 & 7,571 & 7,391 \\
\hline
\end{tabular}

Source: World Development Indicators Online

Employment in aerospace increased from 2,761 in 1980 through 4,000 in 1985 to 5,676 in 1990. Competitive wages (with an average annual growth of $9 \%$ between 1981 and 1985) attracted a high number of foreign staff during the initial years, which was slowly replaced by locally trained skilled labour. As Table 4 shows, aerospace production (which includes MRO as well as parts and components manufacturing) increased substantially during the early years. In 1980, aerospace value added was 192 million US dollars, in 1985 it was 545 million, and topped at 651 million in 1988, with an average annual growth of $17 \%$ over the period 1980 to 1988 . Between 1980 and 1985 exports increased from 106 to 355 million US dollars, at an average rate of 29\%. By 1990, Singapore's exports increased to 528.7 million dollars. Singapore was still a net importer, mainly due to the new aircraft and equipment purchases of SIA. According to Pang and Hill (1992), aerospace imports were more than 50\% higher than exports in 1981 and 1985.

The aerospace industry's performance was equally remarkable in comparison with other latecomers. In 1983, Singapore forged ahead of the local aircraft designer Brazil in terms of value added (332 vs. 301 million US dollars). The difference is even greater in terms of labour productivity, given that Singapore achieved this value added level with $1 / 3 \mathrm{rd}$ the labour force of Brazil. Already by 1981, the level of labour productivity in the latecomer Singapore (81.1 US dollars per person engaged) was higher than in the USA (72.9). This was of course achieved by concentrating on the MRO segment and on one cluster, while the USA had a more diverse structure. 
Box 1 Introduction to the civil aircraft MRO market

The civil MRO market comprises of four segments. We provide a brief overview of the nature and frequency of the work they entail, the cost structures, and the type of companies involved in the activity.

Airframe heavy maintenance refers to what is called as ' $\mathrm{C}$ and D-checks' in commercial aviation. C-checks include a detailed inspection of the airframe and aircraft components, and corrosion prevention. C-checks are due after 2,500-3,000 flight hours and may require 2 to 4,000 man-hours work, usually take 3 days. D-checks refer to a comprehensive structural inspection and overhaul of the aircraft and can take up to 30 days, depending on the size of the aircraft. Since airlines can hardly afford keeping planes on ground for such a long period, they divide the work and carry out the inspection and overhaul in the form of ' $\mathrm{C} 1-\mathrm{C} 4$-checks'. All of these operations are carried out mainly by aircraft operators directly or through a subsidiary (still around $75 \%$ of the global MRO industry), and by independent MRO providers. Airframe heavy maintenance accounts for around $18 \%$ of global MRO turnover, nearly $70 \%$ of which is labour cost and $20 \%$ is material costs, such as solvents, fasteners and standard parts and airframe parts. Replacement parts, or 'rotables', are often provided by airlines.

Line maintenance refers to the most frequent, lighter checks carried out on a daily basis in order to ensure that the aircraft remains flight worthy. These are the so-called transit checks, daily and weekly checks, A and B checks, which include simple visual checks, trouble shooting, defect rectification, overnight maintenance and component replacement. Providing these services accounts for one-fifth of all MRO revenues. Line maintenance is almost entirely done by airlines themselves. In about $10 \%$ to $15 \%$ of the cases they outsource it to subsidiaries or other contract agents. This is overwhelmingly a labour-intensive work; material costs incur expendables and consumables.

Engine overhaul is the largest segment, accounting for around $40 \%$ of global MRO turnover. It aims at restoring designed operational conditions of an engine according to performance guidelines established by the manufacturer. This is carried out by disassembling, inspecting the engine, repairing or replacing of parts if needed, re-assembly and testing. Some 'life-limited parts' have a prescribed replacement interval; otherwise engine overhaul takes place on an as-needed basis. The frequency of engine overhauls varies largely, between 4.5 and 24 thousand engine hours, similarly to the costs, which could vary between 0.45 and 5.5 million dollars. Materials account for almost two-third of the costs. Engine overhaul is carried out mainly by original equipment manufacturers $(44 \%)$, followed by aircraft operators $(25 \%)$, independent companies (13\%, such as ST Aerospace, or Standard Aero, MTU, SR Technics, Aerothrust, etc.) and airline subsidiaries (18\%, i.e., Delta Tech-Ops, Air France Industries and Lufthansa Technik).

Component maintenance, repair and overhaul activities amount to around a quarter of the global MRO industry. These involve the maintenance, repair and overhaul of the main systems, including wheels and brakes, avionics, auxiliary power unit (APU), fuel systems, hydraulic power, flight controls, thrust reversers, landing gear, electrical systems, on-board environmental control and entertainment and other systems. Wheels and brakes are exposed to the heaviest duty and this is the largest cost item in MRO, followed by avionics and APU. These three activities account for $45 \%$ of the segment's turnover. Component MRO is the sub-market with the lowest concentration of firms, given the relatively higher competition on lower tiers in the aerospace supply chain. Original equipment manufacturers are the most important actors in the APU, avionics and fuel systems sub-segment, the rest is dominated by airlines providing in-house MRO or outsourcing it to subsidiaries or independent firms. Material costs are more important than labour costs when it comes to component MRO, especially in the case of wheels and brakes, APU, hydraulics and flight control systems and fuel systems. The most labour-intensive activities are electrical, landing gear and thrust reverser MRO. Specialist services are most important in the avionics sub-segment.

Source: Aeronautical Repair Station Association, 2009, 'Global MRO Market Economic Assessment ${ }^{8}$ 


\subsection{The emerging sectoral innovation system}

By the late 1980s, the Singapore aerospace industry accumulated capabilities to locally assemble older generation fighter and trainer aircraft, learned to upgrade them in collaboration with US manufacturers. It also gained capabilities to assemble and repair helicopters. It became a competitive MRO hub in South East Asia, receiving certifications not only for aircraft in the fleet of RSAF but also for the growing civilian fleet of the state owned SIA. ${ }^{9}$

Unlike Brazil or India, Singapore did not establish public research organisations or training institutes entirely dedicated to aeronautical engineering. MRO activities and parts manufacturing do not require as complex technological capabilities as designing and producing aircraft. Yet, an active governmental role was crucial to provide incentives for firms to locate in Singapore and to invest in technological capabilities with a view of a long-term presence. Part of the government's role was to develop the strategic location of Singapore into a global transportation hub and a regional financial centre. In turn, this provided the basis for a constant demand for air transport related services and MRO with potential scale advantages. The other important role of the government was facilitating the accumulation of advanced technological capabilities through tax incentives for firms, public procurement (including military procurement), favourable immigration policies, and investing in education and training.

The financial incentives, the intensive flow of knowledge and technology provided the basis for the industrial activities to emerge at the Changi/Loyang and Jurong aerospace clusters. Not counting the sales offices of airframe makers, three different kinds of companies were located in Singapore: MRO providers, such as SAI or the Engineering department of SIA (later joined by other providers, such as HAECO of Hong Kong); and parts and component supplier companies from the second and third tiers of the global aircraft industry. ${ }^{10}$ In addition, Aerospatiale represented a top-tier company from the helicopter business.

The close collaboration between the MRO providers and parts and component suppliers was crucial for the technological learning especially in the commercial segment. Such ties represented the main fibres of the sectoral innovation system, which was at the time being, adoption and diffusion of state-of-the-art technological knowledge. Moreover, SAI benefited heavily from both the high public defence spending on RSAF fleet expansion and maintenance, and also from the proximity of related industrial activities (electronics, precision engineering) its sibling companies were involved with. The role of EDB as an efficient gatekeeper between government policies and industry needs made it also a primary actor in the emerging sectoral innovation system.

Evidently, aerospace firms in Singapore were actively learning to apply advanced technologies to assemble and modify technologically complex aircraft that were at least 'new to the country'. MRO firms of Singapore learned to work efficiently and at competitive rates. For a comparison, repair and overhaul man-hours were reported to be 16 to 25 US dollars in Singapore, in comparison with 25 to 50 dollars in the US and 30 to 45 dollars in Europe. ${ }^{11}$ From the 1980s, the industry depended not only on military demand but also on the rapidly growing commercial market. The primary channels of technology acquisition were foreign direct investments and licensing. The 1980s brought 
along capabilities expansion through foreign investment, especially from the USA (air frame structures, systems and equipment MRO, manufacturing of turbine blades, compressors and landing gear). Singapore Aerospace was the main military producer, but a number of other transnational companies such as Sundstrand, Honeywell and Aerospatiale (Eurocopter) located a regional headquarter in Singapore which increasingly used local suppliers for production of smaller parts and the provision of engineering services.

The emerging sectoral system of innovation in aircraft was embedded in an emerging national innovation system which provided a strong knowledge base in science and engineering, access to foreign experts but also to a growing pool of locally educated, competitive labour force. The government provided strong incentives for start-up companies in forms of tax holidays, investment allowances, training grants and investment guarantees. The Loyang Industrial Estate near Changi airport was the first aerospace industrial park which provided ready-built premises and a good infrastructure for new companies. The strong education system offered a full spectrum of vocational, technical and engineering programmes.

The emergence of the national and the sectoral innovation systems were carefully designed by the government with a goal to benefit from high-value added, high-wage jobs in engineering-intensive activities. The sectoral system was designed to make benefit of Singapore's geographical location. These included the economic and air transport growth in the Asia-Pacific region, the cultural connections with China, and airlines' need to cut costs through a low-cost maintenance location and product support centre.

Singapore would not have been able to manage its knowledge resources in times of economic shocks so efficiently without the emergence of an aerospace innovation. The system, unlike in any other emerging countries, learned quickly to react and shift innovative and productive resources to new areas with potential competitive advantage.

\section{Interruptions and smooth transitions}

The most intriguing feature of the emergence of the aircraft industry of Singapore is the lack of long-lasting crises during the 1980s and 1990s, which characterised the global industry and other latecomers. The sector was rather successful in Singapore in avoiding two potentially severe crises of macroeconomic origin. In 1985, the disproportionately larger growth of wages compared to productivity caused a decline in competitiveness and slowed down export growth and foreign investments. Hill and Pang (1988) argued that apart from a drop in exports and imports, the industry was relatively unaffected, owing to the instant intervention of the government. We can also see that trainer upgrading and helicopter assembly activities provided sufficient orders for the industry during this time. The crisis had no effect on value added, which was in fact growing by $38.5 \%$ in 1985 due primarily to the defence industries. The Asian financial crisis of 1997 had also relatively limited impact in comparison with the Indonesian aircraft innovation system. The question addressed here is how did the aerospace industry in Singapore sustain growth? 
Table 4 Key indicators of the SAI, 1977-2007

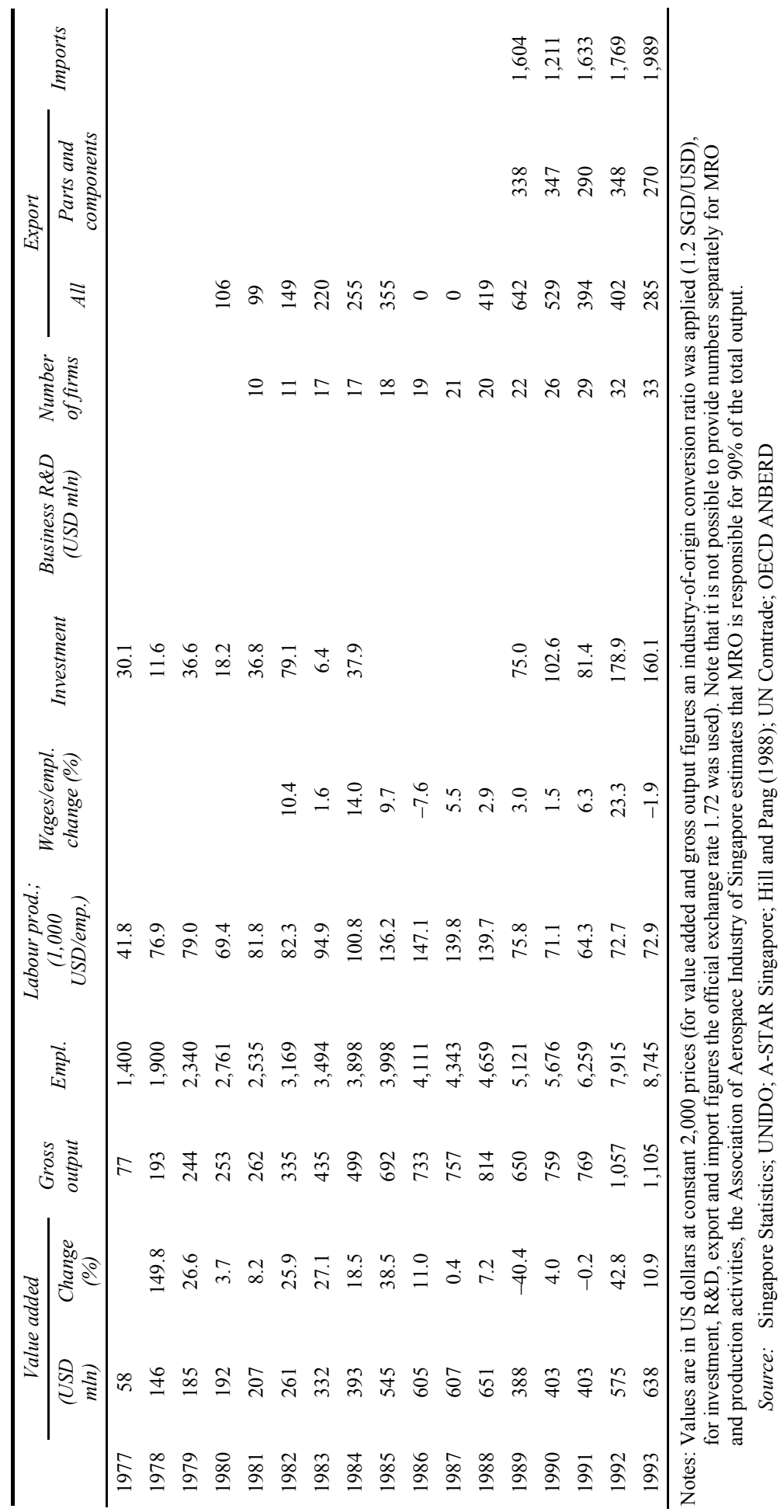


Table 4 Key indicators of the SAI, 1977-2007 (continued)

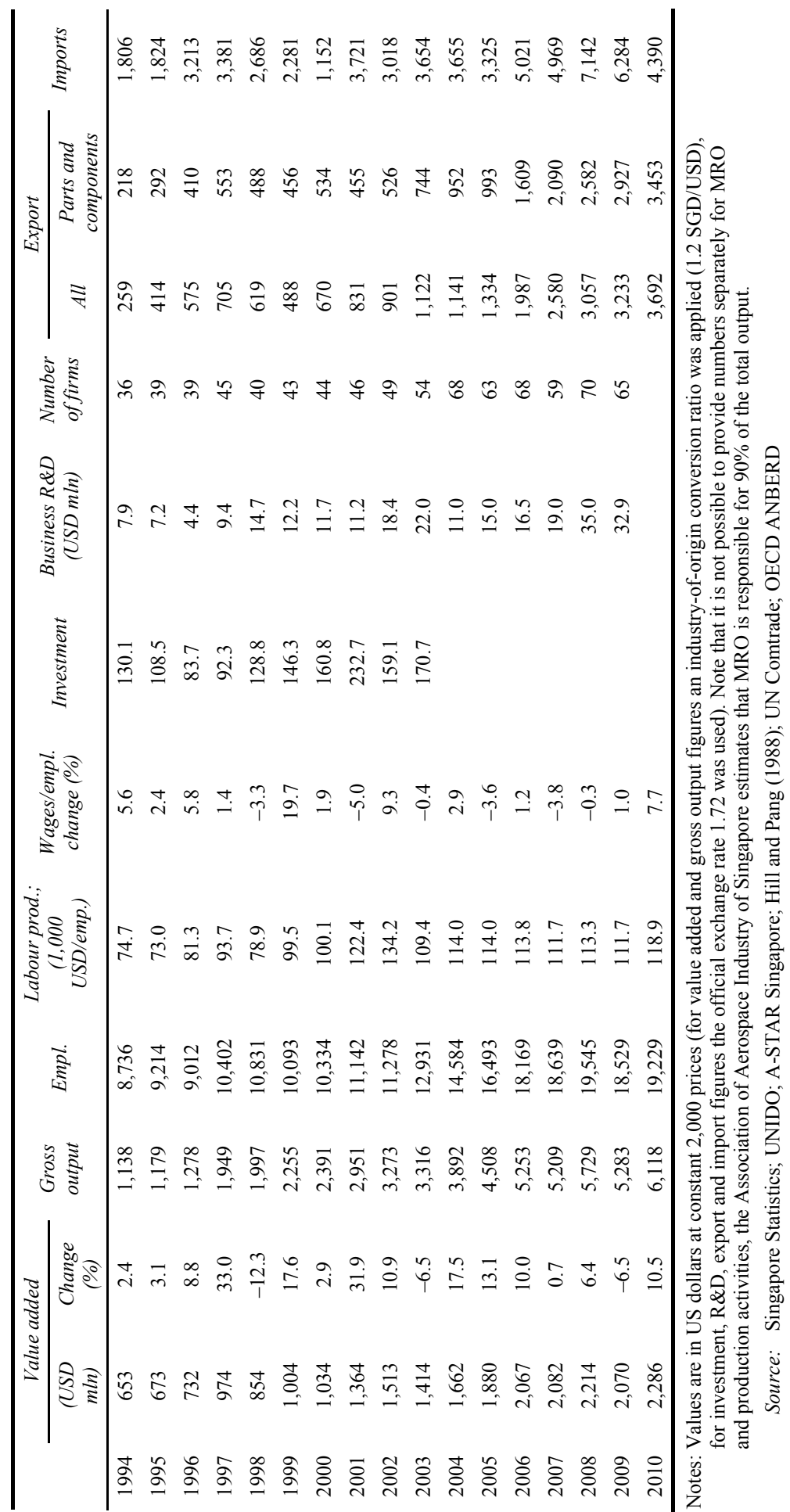




\subsection{Privatisation, reorganisation and internationalisation}

By the time the global aircraft industry slipped into its most severe crisis in its history in 1990, Singapore has already initiated a fundamental overhaul of its aerospace industry and innovation system. It was triggered by the declining sales and value added experienced in 1989 due to the underperformance of the military segment. In 1989, value added dropped below 1984 levels, sales below 1985 levels, labour productivity declined in a year by $46 \%$. Singapore was quick to realise that the global competitive environment was transforming toward greater internationalisation. It also saw the limits of its domestic market and the growth potential of the Asia Pacific region. This realisation led to a new strategy which implied steering away from the defence industries and expanding the commercial segment. Singapore rather swiftly and efficiently introduced measures to rejuvenate its aerospace industry by privatisation, reorganisation and internationalisation of its largest holding, Singapore Technologies. ${ }^{12}$

In order to finance further expansion, the government privatised a third of its stake in Singapore Technologies Aerospace (ST Aerospace) in June 1990. The offering was highly successful (shares were 33 times oversubscribed) and raised 150 million $\mathrm{SGD}^{13}$, almost the amount of the company's annual turnover. Commercial maintenance activities were shifted to a spin-off company, Singapore Aviation Services (SASCO) already before the partial flotation. At the beginning of the 1990s, more than $2 / 3$ rd of ST Aerospace's business was coming from the defence segment. The aim was to increase commercialisation and increase foreign sales. The turnover of ST Aerospace from foreign operations was already as high as $32 \%$ by 1989 , which increased to $50 \%$ by 1990. ${ }^{14}$ In 1990, the company entered the European market by setting up ST Rotables at Stansted Airport in the UK. Demand from US operators has already been significant for ST Aerospace. Since its hangars were working with full capacity, a potential for further expansion was opening a maintenance facility in the USA, closer to potential customers. ST Aerospace Mobile was established in 1991 with a 20-million-US-dollars green-field investment in Mobile, Alabama, aimed at providing maintenance and cargo conversions for Fedex. ${ }^{15}$ It also established operations in Los Angeles by acquiring a local sheet-metal supplier of Boeing with an aim of moving closer to its customers. At the same time, the company's attempts to establish presence in neighbouring Indonesia (on the island of Batam) have been unsuccessful.

ST Aerospace also took a major step in venturing into a new area of co-development. It signed a deal with the French Aerospatiale (now Eurocopter) and China National Aero-Technology Import and Export Corporation (CATIC) to jointly develop a five-seat helicopter, the EC-120 (original designation P120L). The joint venture started in 1990. Eurocopter owned a $61 \%$ share and was responsible for the instrument panel, landing gear, seats, rotor system, transmission, final assembly, flight test and certification. CATIC (through Hafei Aviation Industry Company) owned a $24 \%$ stake and was responsible for cabin structure and doors, engine cowlings, pod central and intermediate structure and fuel system. ST Aerospace owned $15 \%$ of the project and was responsible for tail boom, fin, horizontal stabiliser, 'fenestron' (tail rotor), general doors and instrument pedestal development. The design was successful, but ST Aerospace did not participate in the production later on. Instead, it took on duties in line with what it was doing before: MRO and aircraft refurbishment. In the mid-1990s, it upgraded the F-5 fighters of the RSAF with new radar, avionics and weapons systems. In 1999, it successfully developed a method for passenger to cargo conversion of B-757s. In 2002, it 
entered into a strategic cooperation with BAe Systems of the UK to add new avionics suit and mission computer to some of the F-16s Singapore acquired, resulting in the 'Falcon One' upgrade. It also upgraded Super Puma helicopters and C-130 Hercules transport planes for the air force over the 1990s and 2000s (Table 2). In 2006 the company entered the mini UAV systems business after being contracted by the RSAF. During the 2000s, STA Aero continued the internationalisation. It opened another facility in the US in San Antonio, Texas in 2006. It entered the Chinese market (established MRO facilities in Shanghai in 2004, logistics in Guangzhou in 2007); in 2006 it acquired SAS Component $\mathrm{A} / \mathrm{S}$ in Denmark and established a subsidiary in Panama. As a result of the growing on the international markets, ST Aerospace tripled its revenue between 1996 and 2007 and increased profits by nine-fold to 143 million dollars (Figure 1).

ST Aerospace was the largest, but by far not the only company in the industry. The number of companies in fact increased from 20 in 1988 to 33 by 1992. This increase was only partly a result of the creation of subsidiaries. This period also saw major new investment in the sector, with an average of 120 million dollars between 1989 and 1995 (Table 4). By the mid-1990s, major companies such as GE, Goodrich, Hamilton Sundstrand ${ }^{16}$, Liebherr, Rockwell Collins or Rolls Royce Engines had established presence, expanding the aircraft and engine subsystems and avionics production and repair knowledge base in the country. The largest competitor in the MRO industry for ST Aero was another state-owned company, SIA. Over the years, SIA Engineering has responsible for the engineering work on the airline's expanding large aircraft fleet. In 1992, SIA's Engineering Division became a separate subsidiary, SIA Engineering, with an intention to increase foreign presence. SIA Engineering similarly expanded its MRO operations in the late 1990s and early 2000s and set foot in Australia, the USA, Hong Kong, Indonesia, Philippines and Vietnam. Between 1996 and 2007 its global employment increased from 4,200 to 6,100, its turnover grew from 407 to 539 million dollars (Figure 1). It is also clear that SIA Engineering was forced to react more quickly than ST Aerospace to the latest crisis which hit the industry, since the ST Engineering conglomerate could offset missing aerospace revenues from the revenues of its better performing other divisions, such as electronics.

Figure 1 MRO revenues and employment of ST Aerospace and SIA Engineering, 1996-2008

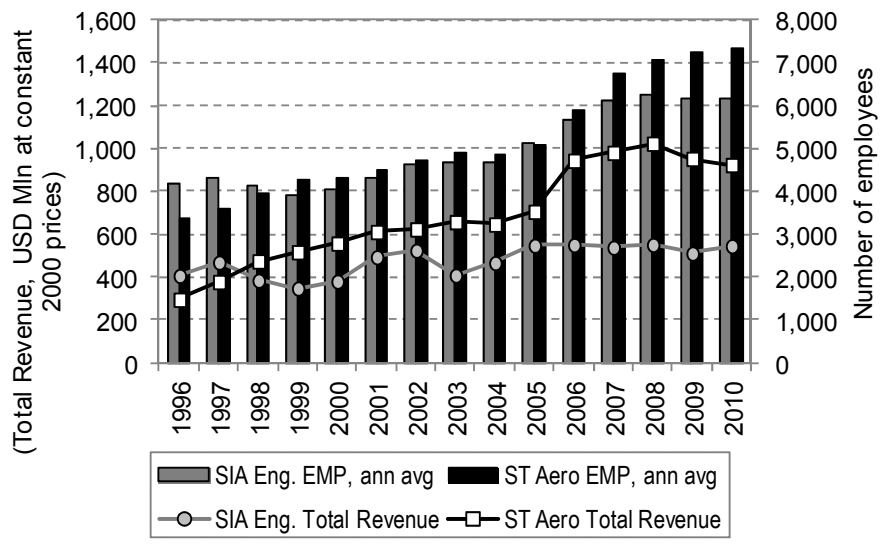

Note: Constant price series converted with a 1.72 SGD/USD rate for 2000.

Source: SIA Engineering and ST Aerospace annual reports, various years 


\subsection{An innovation-led growth trajectory}

In short, during the early 1990s, Singapore's partly state-owned companies increasingly focused on the commercial markets. They realised growth through global expansion. At the same time, the knowledge base of the industry strengthened substantially through a focus on innovation and pre-competitive research. Targeted Aerospace R\&D support programmes were designed by the EDB and implemented by the newly formed NSTB and later by the A-Star. The programme defined new R\&D directions based on inputs from major companies in the sector: advanced materials, manufacturing processes and automation, information and communication, inspection and non-destructive testing, and computational modelling and dynamics.

It may seem paradoxical that the industry as a whole is performing well, despite the relatively low R\&D inputs in comparison with other sectors in Singapore as well as with other countries. In 2009, aeronautical engineering employed less than $1 \%$ of Singapore's researchers and received hardly more than $1 \%$ of all R\&D expenditures. Aircraft manufacturing companies in Singapore owned only 14 patents in the same year. ${ }^{17}$ In an international comparison, Singapore's aerospace R\&D of 2005 was 15.3 million US dollars, compared with 155.5 million of South Korea, 340 of Japan or 672 million of Canada. Remarkably, Singapore managed to establish a 'low-cost' aerospace innovation system owing to its specialisation in the MRO and parts and components manufacturing segments. Nevertheless, due to intensive linkages with other related industries, aircraft manufacturing in Singapore benefited from R\&D input into fields such as electronics and electric, mechanical, computer, and material science and engineering, which received around $85 \%$ of the 2.5 billion USD R\&D expenditures.

These close linkages explain how a shift to knowledge-intensive activities occurred in aerospace in harmony with the overall shift of the national innovation system. Singapore consciously increased the national and corporate R\&D during the last two decades. From 380 million dollars in 1990, gross expenditure on R\&D increased to 3.4 billion dollars by 2007 (Figure 2). Although in comparison with other OECD countries, Singapore's aerospace R\&D is relatively low (15.3 million USD in 2005, as opposed to 155 million in South Korea, 340 million in Japan or 1.9 billion in Germany), but its aerospace activities are centred around selected segments which are closely related to existing local capacities (such as avionics and the electronics industry or precision engineering and engineering capabilities in general).

A good indicator of the strong performance of the national and sectoral innovation systems is how the aerospace industry weathered the 1997 the Asian financial crisis. Due to declining demand of partners in the region, the crises caused a $12 \%$ decline in value added by 1998 , but growth resumed the following year at an $18 \%$ rate. The reason for the quick recovery can be explained partly by the strong macroeconomic and financial fundamentals with which Singapore entered the crisis (Chia, 1999). However, even if the Singapore dollar depreciated against the US dollar, it appreciated against other Southeast Asian currencies and regional demand for aerospace products (including repair) was falling. But the regional markets were declining (aerospace exports dropped by $11 \%$ drop from 1997 to 1998 and by $20 \%$ from 1998 to 1999). Yet, the industry showed strength by having expanded to overseas markets, and missing regional demand was complemented by increased military orders. On the other hand, despite the crisis, Singapore continued to increase $R \& D$ expenditures. The experience also gave incentives for companies to further expand overseas presence (see above ST Aero's strategy in the 2000s). In an 
international comparison, with its 1.4 billion US dollar income, ST Aero was the largest independent MRO provider in the world in 2010 and the third largest MRO provider in absolute terms after Lufthansa Technik and Air France - KLM Engineering and Maintenance. ${ }^{18}$ The SIA Engineering company is also among the strongest in Asia, with its 0.8 billion USD revenue, it also outperformed Hong Kong-based (but regionally spread) HAECO in 2010 (with a revenue of 0.5 bln USD). A main reason is that many airlines, from Japan, China and the Middle East among others, chose Singapore to perform overhaul operations for virtually all types of airliners, making use of the 'one-stop-shop' solutions, the efficient and reliable scheduling.

Figure 2 R\&D Expenditures of Singapore, 1981-2009

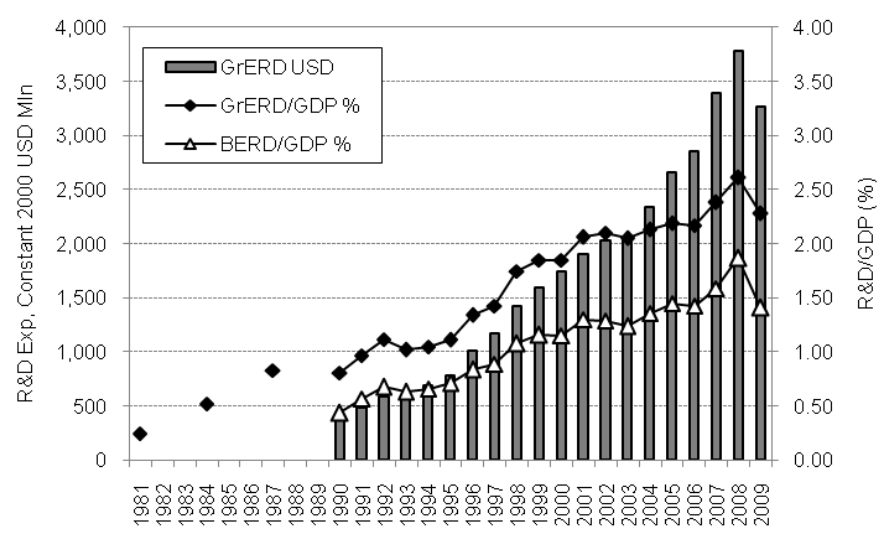

Note: Constant price series converted with a 1.72 SGD/USD rate for 2000.

Source: 'National Survey of R\&D in Singapore 2009', Agency for Science,

Technology and Research, Singapore; Yearbook of Statistics

Singapore, various editions

At the moment, Singapore's aerospace innovation system and production facilities are constantly expanding. The number of aerospace graduates has been constantly growing and is expected to reach 1,000 annually in $2010 .{ }^{19}$ Current manufacturing activities focus on avionics and aircraft and engine parts and components. The latest incentives for investment include a 300 hectares new industrial park at a renovated airport in Seletar to be completed in 2018. Three major companies that already indicated their intention to move there and expand capacities are EADS's helicopter maker Eurocopter and the engine manufacturers Pratt \& Whitney and Rolls Royce. The latter intends to bring engine parts manufacturing (wide chord fan blades), engine assembly and test work to Singapore to serve the Asian large aircraft market. This shows once again that transnational companies value Singapore's location and their contribution made Singapore a 'first-mover latecomer'.

Singapore's future competitiveness lies in the still increasing performance of the aerospace innovation system. It can draw from a strong knowledge stock. Almost two-third of all researchers (60\% to $64 \%)$ has been working in the field of engineering and technology in the last decade. Their number in business enterprises has been increasing substantially, from 5,841 in 2002 to 11,732 in 2007 (in terms of full time equivalent). Singapore's commitment to invest in education, training and R\&D is well above the regional average. Both the National University of Singapore (NUS) and the 
Nanyang Technological University offer world-class education and research in science, engineering and management. Contrasting the NUS with the University of Malaya (its predecessor before Singapore's independence) highlights how a favourable government policy and strategic university governance in Singapore succeeded in attracting and create new talent: by attracting foreign staff and students through favourable immigration policy and often subsidised studies instead of restrictive admittance and immigration regulations, and by investing in facilities through effective cost sharing, fundraising and collaboration with industrial partners (Salmi, 2009). But parallel to the investment in a knowledge-based growth, Singapore's EDB still provides incentives to invest in the MRO segment similarly to the early years of emergence.

\section{Conclusions}

Within three decades since its emergence, a strong aircraft industry emerged in Singapore. The sector is among the top ten in the world in terms of value added, with output levels similar to Brazil (Table 5). However, only $10 \%$ of this is actual manufacturing, the other $90 \%$ covers MRO activities. ${ }^{20}$ The aircraft industry in Singapore differs from other latecomers in many ways. It did not seek prestige through producing a locally designed aircraft, rather accumulated capabilities to become a highly competitive MRO hub. Since 1980, it was one of the very few countries that managed to sustain growth in the sector. It was also one of the first Asian producers (along with Hong Kong) to benefit from the new winds of internationalisation in the 1990s.

In short, the emergence of the industry and sectoral innovation system was successful because of the mixed policy of developing a commercially-focused, military-aided system to accumulate technological capabilities. Hill and Pang (1988) drew attention to the major differences between the way Singapore and Indonesia promoted their aerospace industries. While Singapore followed an outward-looking strategy with a strong repair and services orientation, Indonesia was inward looking, aimed at manufacturing complete aircraft by a national champion that was overly dependent on public subsidies. Singapore's government played an active role in facilitating the emergence of a sectoral innovation system. It invested heavily in infrastructure, by building the Changi airport to boost private demand for aviation-related businesses, and invested in human resources, by financing engineer education, skilled worker training and attracting talents and experts ${ }^{21}$ with a pro-active immigration policy. Public funds helped the flag carrier SIA expand its global network, and military contracts for local assembly and refurbishment financed technological investments at SAIs. Singapore capitalised on its location advantages and attracted many foreign firms from the second and third tiers of the global aerospace industry by providing tax breaks and advantageous facilities in industrial parks. The EDB ensured a close collaboration between the main stakeholders of the sectoral innovation system.

The strategic specialisation in MRO activities and parts and component manufacturing and the proximity of related industries also efficiently substituted missing capabilities. The main function of the aerospace innovation system during these years was the adoption and diffusion of advanced technologies to the local context. The development of industries such as electronics, computers and precision manufacturing offered synergies, which made the aerospace sector competitive. The strategic thinking 
and such close linkages were the main reason why Singapore managed to respond to competitive challenges quickly.

Table 5 Aerospace value added of selected countries, 1980-2007

\begin{tabular}{lcccccccc}
\hline & \multicolumn{3}{c}{ Value added (USD millions) } & & \multicolumn{3}{c}{ Average annual growth rate (\%) } \\
\cline { 2 - 4 } & 1980 & 1990 & 2000 & 2007 & & $1980-1990$ & $1990-2000$ & $2000-2007$ \\
\hline Brazil & 299 & 630 & 2,348 & 1,924 & & 7.7 & 14.1 & -2.8 \\
Canada & 2,105 & 2,951 & 4,124 & 5,221 & & 3.4 & 3.4 & 3.4 \\
China & $3,298^{\mathrm{a}}$ & 2,118 & 2,297 & 7,072 & & -3.9 & 0.8 & 17.4 \\
France & 1,549 & 1,820 & 3,023 & 3,126 & & 1.6 & 5.2 & 0.5 \\
India & 44 & 87 & 46 & 134 & & 7.1 & -6.2 & 16.5 \\
Indonesia & 11 & 48 & 227 & 73 & & 15.9 & 16.7 & -15.0 \\
Mexico & 138 & 92 & 221 & 236 & & -4.0 & 9.2 & 0.9 \\
Singapore & 192 & 403 & 1,034 & 2,121 & & 7.7 & 9.9 & 10.8 \\
USA & 58,527 & 69,868 & 48,926 & 99,144 & & 1.8 & -3.5 & 10.6 \\
\hline
\end{tabular}

Notes: Million USD at constant 2000 prices.

${ }^{a}$ Refers to 1981 . Since applying official exchange rates would underestimate output value, national currencies were converted with the following industry-specific unit value ratios: $1.09 \mathrm{BRL} / \mathrm{USD} ; 1.55 \mathrm{CAD} / \mathrm{USD} ; 4.6 \mathrm{CNY} / \mathrm{USD} ; 1.96 \mathrm{EUR} / \mathrm{USD}$; 13.6 INR/USD; 4201 IDR/USD; 12.73 MXN/USD; 1.2 SGD/USD.

Sources: UNIDO IndStat (Singapore, India, Indonesia); OECD STAN Online (Canada, France, Mexico, USA); IBGE (Brazil); China Statistical Yearbook on Science and Technology, various years (China); for description see Vertesy (2011); Industries defined according to ISIC Rev. 3 class 353 Aircraft and spacecraft manufacturing

The sectoral innovation system was forced to respond to the global crises in the aerospace industry, which was triggered by defence spending cuts and oil price increases at the end of the Cold War and beginning of the Gulf War. Singapore was one of the first countries to readjust the scope of innovation and production according to the changed competitive environment. It quickly realised the advantages it can gain from the internationalisation of supply chains and the dismantling of previously vertically integrated company structures in Europe and North America. Singapore had a potential to become a low-cost regional supply and maintenance base, but only if it could expand the capacities (gaining economies of scale by expanding internationally) and by increasing its portfolio of design and production capabilities. An alternative was to expand the component manufacturing activities - the EC-120 helicopter project offered a point of entry to joint development. However, Singapore continued to concentrate on its competitive strength, MRO activities. This was warranted given the expectations of growth of Asian economies, which offered potentials for the aviation industry and supporting industries. In order to make the state-owned companies more flexible for international expansion, the government chose partial flotation in the case of ST Aerospace, and spinning off the Engineering Division of SIA. (Note the similar considerations behind the privatisation of Embraer in 1994.) Because of responding quickly to the new competitive environment, Singapore's aerospace industry has 
managed to maintain a competitive edge in the rapidly growing region, despite existing and emerging competition in Hong Kong, Thailand and Malaysia.

Unlike any other emerging aerospace producer country, Singapore successfully managed a 'transition without interruption' in the sectoral innovation system. The aim and means of achieving competitiveness were well designed in the emerging innovation system, which minimised institutional inertia in a time of transition. For instance, the product structure and repair activities did not have the long lead time which aircraft producers had to deal with. The similarity between existing capabilities and those required in the new system was high and highly compatible. What companies had to learn was organisational innovation, in addition to a rapidly developing avionics segment but a rather incrementally changing engine or aircraft parts production and repair technologies. Moreover, the innovation system has had a number of actors specialised in fostering knowledge exchange, such as the Association of Aerospace Industries in Singapore, private consultants or government funded R\&D agencies. In addition, a sound macroeconomic environment and high economic growth ${ }^{22}$ were similarly important for a swift transition. As demand for air travel continues to soar in Asia, Singapore remains well positioned for reaping further growth from its well-functioning sectoral innovation system.

\section{Acknowledgements}

The author would like to thank the participants of the 2011 Aerospace Conference at UQAM in Montreal for their feedback and comments, with special thanks to Jorge Niosi. The comments received from Adam Szirmai on an earlier version of this paper as well as from the two anonymous reviewers have also been most helpful. All remaining errors are the author's own.

\section{References}

Abernathy, W.J. and Utterback, J.M. (1978) 'Patterns of industrial innovation', Technology Review, Vol. 80, No. 7, p.40.

Aw, B-Y. (1991) 'Singapore', in Papageorgiou, D., Michaely, M. and Choksi, A.M. (Eds.): Liberalizing Foreign Trade. The Experience of Korea, the Philippines, and Singapore, B. Blackwell, Oxford, OX, UK, Cambridge, Mass.

Chia, S.Y. (1999) 'The Asian financial crisis. Singapore's experience and response', in Arndt, H.W. and Hill, H. (Eds.): Southeast Asia's Economic Crisis: Origins, Lessons, and the Way Forward', Institute of Southeast Asian Studies, Singapore.

Cimoli, M., Dosi, G. and Stiglitz, J.E. (2009) Industrial Policy and Development: the Political Economy of Capabilities Accumulation, Oxford University Press, Oxford, Toronto.

Freeman, C. and Perez, C. (1988) 'Structural crises of adjustment: business cycles and investment behaviour', in Dosi, G., Freeman, C., Nelson, R.R., Silverberg, G. and Soete, L. (Eds.): Technical Change and Economic Theory, Pinter, London, New York.

Freeman, C. and Soete, L. (1997) The Economics of Industrial Innovation, 3rd ed., MIT Press, Cambridge, Mass.

Hill, H. and Pang, E.F. (1988) 'The state and industrial restructuring. A comparison of the aerospace industry in Indonesia and Singapore', ASEAN Economic Bulletin, Vol. 5, No. 2, p.152. 
Hobday, M. (1995) 'East Asian latecomer firms: learning the technology of electronics', World Development, Vol. 23, No. 7, pp.1171-1193.

Kim, L. (1980) 'Stages of development of industrial technology in a developing country: a model', Research Policy, Vol. 9, No. 3, pp.254-277.

Kim, L. (1997) Imitation to Innovation: The Dynamics of Korea's Technological Learning, Harvard Business School Press, Boston.

Lall, S. (1992) 'Technological capabilities and industrialization', World Development, Vol. 20, No. 2, pp.165-186.

Lall, S. (2004) 'Reinventing industrial strategy: the role of government policy in building industrial competitiveness', G-24 Discussion Paper Series, UNCTAD, Geneva.

Malerba, F. (2004) 'Sectoral systems of innovation: basic concepts', in Malerba, F. (Ed.): Sectoral Systems of Innovation: Concepts, Issues and Analysis of Six Major Sectors in Europe, Cambridge University Press, Cambridge.

Mani, S. (2010) 'The flight from defence to civilian space: evolution of the sectoral system of innovation of India's aerospace industry', CDS Working Paper No. 428, Centre for Development Studies, Trivandrum.

Marques, R.A. (2004) 'Evolution of the civil aircraft manufacturing innovation system: a case study in Brasil', in Mani, S. and Romijn, H. (Eds.): Innovation, Learning and Technological Dynamism of Developing Countries, United Nations University Press, Tokyo, New York.

Niosi, J. and Zhegu, M. (2005) 'Aerospace clusters: local or global knowledge spillovers?', Industry and Innovation, Vol. 12, No. 1, pp.1-25.

Niosi, J. and Zhegu, M. (2008) 'Innovation system lifecycle in the aircraft sector', Paper presented at the DRUID 25th Celebration Conference, 17-20 June 2008, Copenhagen, Denmark.

Pang, E.F. and Hill, H. (1992) 'Government policy, industrial development and the aircraft industry in Indonesia and Singapore', in Liemt, G.V. (Ed.): Industry on the Move: Causes and Consequences of International Relocation in the Manufacturing Industry, International Labour Organization, Geneva.

Perez, C. and Soete, L. (1988) 'Catching up in technology: entry barriers and windows of opportunity', in Dosi, G., Freeman, C., Nelson, R.R., Silverberg, G. and Soete, L. (Eds.): Technical Change and Economic Theory, Pinter, London, New York.

Romanelli, E. and Tushman, M.L. (1994) 'Organizational transformation as punctuated equilibrium: an empirical test', The Academy of Management Journal, Vol. 37, No. 5, pp.1141-1166.

Salmi, J. (2009) The Challenge of Establishing World-Class Universities, The World Bank, Washington, DC.

Tushman, M.L. and Anderson, P. (1986) 'Technological discontinuities and organizational environments', Administrative Science Quarterly, Vol. 31, No. 3, pp.439-465.

Vertesy, D. (2011) 'Interrupted innovation: emerging economies in the structure of the global aerospace industry', $\mathrm{PhD}$ dissertation, Datawyse, Maastricht.

Vertesy, D. and Szirmai, A. (2010) 'Interrupted innovation: Innovation system dynamics in latecomer aerospace industries', UNU-MERIT Working Paper No. 2010-059, UNU-MERIT, Maastricht.

Yun, H.A. (2004) 'Innovative milieu and cooperation networks: state initiatives and partnership for restructuring in Singapore', in Cooke, P., Heidenreich, M. and Braczyk, H-J. (Eds.): Regional Innovation Systems: The Role of Governance in a Globalized World, 2nd ed., Routledge, London, New York. 


\section{Notes}

1 The party's approval rating was $47 \%$ in 1963 and climbed to $84 \%$ already by 1968 .

2 When the RSAF was formed in 1975, a predecessor organisation already had experience in managing a fleet of early-generation jet fighters and trainers, helicopters and small transport aircraft - with British assistance. A Flying Training School was already established in 1969. Due to tensions in the relations with neighbouring countries, and a perceived threat of invasion, the military and especially the high-tech air force received strong state support.

3 Without an agreement to mutually accept national certification, companies had individually to obtain certification from national and foreign authorities. For instance, the predecessor of ST Aerospace became an FAA certified repair station in already in 1973.

4 'Singapore attracts more' Flight International, 4 January 1986

5 These included: Singapore Aerospace Maintenance Company (SAMCO), Singapore Aerospace Manufacturing (SAM), Singapore Aero-Components Overhaul Company (SACO), Singapore Electronics \& Engineering Ltd. (SEEL), Singapore Aerospace Warehousing and Supplies (SAWS), Singapore Aero-Engine Overhaul Ltd. (SAEOL), and the Samaero company ('Singapore attracts more' Flight International 4 Jan 1986).

6 For details see 'Gradually Global' Flight International: Asian Aerospace Special, 19-25 February 1992.

7 The AS-332 and -532 models, as well as the AS-350 and -550 models are structurally the same; the designation AS-5xx indicates military use, AS-3xx indicates civilian use.

8 URL: http://www.arsa.org/files/ARSACivilAircraftMROMarketOverview-20090821.pdf (accessed on 18 February 2011)

9 The Engineering Division of SIA was responsible for the maintenance of its fleet which by the end of the 1980s consisted of Airbus A300s, A310s, B747-200 and -300s, B757s and DC-10s.

10 The aerospace industry is hierarchically organised into tiers. Companies with main activities in design, assembly and marketing (i.e., Boeing or Airbus) occupy the top tier; component and subsystems manufacturers (i.e., engine makers, such as Rolls Royce or avionic system providers such as Honeywell) are on the second tier; followed by parts and component makers on the third (or lower) tiers. For a more detailed explanation, see Niosi and Zhegu (2005).

11 'Singapore aerospace sprouts wings' Aerospace America, October 1986

12 In 1989, SAIs was reorganised into Singapore Technologies in line with the diversification strategy into commercial aerospace.

13 This equals to around 100 million US dollars at 2000 prices.

14 'Gradually Global' Flight International: Asian Aerospace Special 19-25 Feb 1992

15 The start of the plant in Mobile was slower than the expectations, and still waiting for a 10-million dollar Fedex contract in 1993 ('Investments set for take-off in long-term' The Straits Times January 10, 1993). Yet, by 1999 the company celebrated the delivery of the 1000th aircraft to Fedex, which included B-727s and 747s.

16 Hamilton established presence in Singapore in 1977 as Sundstrand, and currently employs over 800 persons produces and repairs aircraft subsystems. In 2004 Hamilton Sundstrand decided to move auxiliary power units and electric power system components producing capacities from Colorado to Singapore which was seen as a lower cost location.

17 National Survey of R\&D in Singapore 2009, Agency for Science, Technology and Research.

18 According to company Annual Reports, in 2010, the total revenue of LH Technik was $5,322 \mathrm{mln}$ USD, 3,903 mln USD of AFI-KLM E\&M, and 550 of HAECO, Hong Kong.

19 This is an aggregate of all graduates from universities, polytechnics and technical institutes, and includes aeronautical engineering, avionics, aviation management and 'mechatronics'. Additionally, courses started in 2007 to expand the number of precision engineering specialists (Association of Aerospace Industries Singapore, 2010). 
20 The figure has been stable during the 2000s, according to the calculation of the Association of Aerospace Industry Singapore, based, on the EDB, company reports and Frost \& Sullivan analysis. URL: http://i.b5z.net/i/ui/4003513/i/SVAC_-_Industry_Presentation_090917.pdf (accessed on April 2012).

21 Immigrant labour was an overall important knowledge source for Singapore. Immigrant stock increased from half a million in 1980 to 1.5 million in 2005; also relative share in society increased from $22 \%$ to $35 \%$ (World Development Indicators Online).

22 Between 1989 and 1992, annual GDP growth averaged at 8\%. 